\title{
Avaliação do Índice de Atividade de Frangos de Corte em Diferentes Condições de Temperatura em Câmara de Preferência Ambiental
}

\author{
Gabriela de O. Ferrari (IC), Daniella de Jorge Moura (PQ)
}

\section{Resumo}

Este projeto de pesquisa propôs avaliar o comportamento de frangos de corte confinados em uma câmara de preferência ambiental frente a diferentes condições de ambiente térmico. Entretanto, antes da realização do experimento foi necessário realizar uma avaliação sobre o funcionamento da Câmara de Preferência Ambiental (CPA), recém construída no Laboratório de Conforto Térmico II da Faculdade de Engenharia Agrícola, tanto para verificação do sistema de monitoramento de imagens como para verificar se havia a necessidade de calibrar os sensores de temperatura e umidade relativa (UR) do ar da mesma, para o controle do ambiente térmico.

Palavras Chave: Índice de Atividade, Frango de Corte, Câmara de Preferência Ambiental.

\section{Introdução}

Em um sistema de criação de frangos de corte, a temperatura assume relevante importância, uma vez que pode vir a comprometer a função vital mais importante das aves: a homeotermia. Para se adequarem às flutuações de temperatura de ambiente, as aves utilizam alguns mecanismos, como alterações em seu comportamento, para se ajustarem ao ambiente. Para compreender cada vez mais a interferência do ambiente no bem-estar de frangos de corte, 0 uso de câmaras climáticas e monitoramento automático de imagens são ferramentas tecnológicas que vêm sendo cada vez mais utilizadas. Neste sentido o objetivo deste trabalho foi avaliar o índice de atividade das aves criadas em uma câmara climática (CPA) em diferentes condições de temperatura ambiente.

\section{Resultados e Discussão}

Antes de iniciar o experimento, foi necessário verificar se todo o sistema de controle ambiental e de monitoração automática de imagens estavam funcionando corretamente. Para isso, foi feita a calibração dos sensores de temperatura e umidade relativa (UR) de cada um dos 3 compartimentos da CPA, através de datallogers (Onsetß, HOBO H08-007-02) e verificação do sistema de monitoramento de imagens. Concluiuse que o sistema estava funcionando corretamente. Porém, após testes de verificação de alcance dos valores máximos e mínimos desejados dos sensores, constatou-se que os mesmos precisariam de uma nova calibração. Desta forma, com o uso de um Termo-hidrômetro (Instrutherm®, HT-260), os sensores foram calibrados adequadamente. Além disso, foi instalado uma válvula redutora de pressão hidráulica, desenvolvido um sistema de registro automático do consumo de água pelas aves em cada compartimento e, consequentemente, feita a atualização do software de controle ambiental da CPA (versão 3.0 para a 3.1) (Fig. 1).

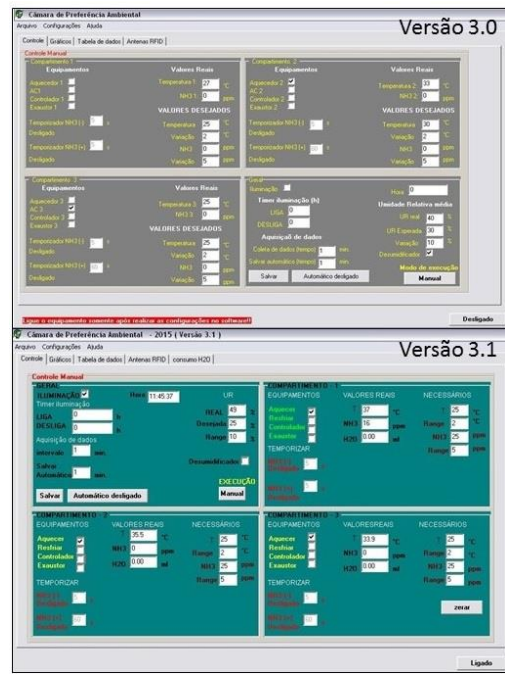

Figura 1. Nova interface do programa (versão 3.1) referente ao controle do ambiente da CPA.

\section{Conclusões}

Com todas as modificações e reparações realizadas, a CPA apresentou-se apta para o recebimento dos frangos.

\section{Agradecimentos}

Agradecimentos ao SAE/PIBIC, pela bolsa de iniciação científica concedida ao primeiro autor.

Berckmans, D. Automatic on-line monitoring of animals by precision livestock farming. International Society for Animal Hygiène - SaintMalo - 2004

Moura, D.J. Ambiência na produção de aves de corte. In: SBEA. 1 ed, 2001, Piracicaba. Ambiência na produção de aves em clima tropical... Piracicaba: NUPEA- ESALQ/ USP, 2001, v.2, p.75-148.. 